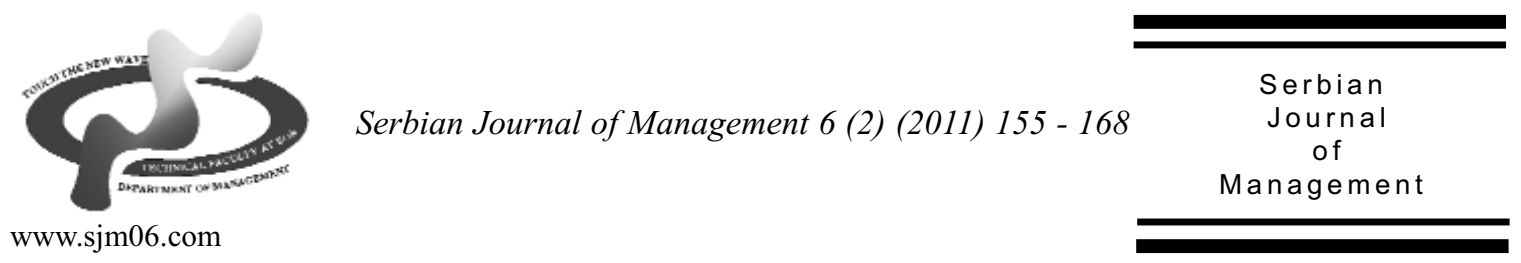

\title{
FINANCIAL MARKET DEVELOPMENT AND CAPITAL STRUCTURE OF LISTED FIRMS - EMPIRICAL EVIDENCE FROM GHANA
}

\author{
James N. Doku ${ }^{a *}$, Charles Komla Delali Adjasi ${ }^{b}$ and \\ Emmanuel Sarpong-Kumankumac

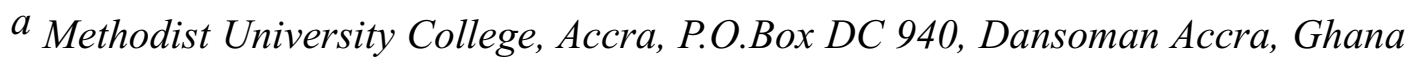 \\ $b$ University of Stellenbosch Business School, Cape Town, \\ P O Box 610, Bellville 7535, South Africa \\ ${ }^{c}$ University of Ghana Business School, Accra Ghana, P.O.Box LG 78 Legon, Ghana
}

(Received 12 November 2010; accepted 15 June 2011)

\begin{abstract}
This study explores the relationship between financial market development and choice of finance (debt-equity) of listed firms in Ghana in a panel data framework. The core concern of this study is to test whether debt and equity finance are complements or substitutes. The study used panel data which involves pooling of twenty-one listed firms on the Ghana Stock Exchange (GSE) over the period 1995-2005. The study finds evidence of complementarity between banking and stock market developments in financing decisions of listed firms in Ghana. The stock market development is indicated to have a positive effect on the capital structure decisions of listed firms. However, substitution effect between debt and equity mainly in favour of equity financing sets in as the financial landscape develops further. This finding emphasises the important role equity markets in developing countries play in capital structure of listed firms.
\end{abstract}

Keywords: Financial market Development, Capital Structure, Complementarity, substitute, Ghana

\section{INTRODUCTION}

Financing decisions have gained much attention in finance literature over the years since the seminal works of ModiglianiMiller $(1958,1963)$, hereafter referred to as MM capital structure irrelevance propositions. These financing decisions vary from country to country, partly explained by institutional and legal environment as well as macroeconomic factors. Most of the studies on the capital structure have been conducted in the context of developed and industrialized nations (Kester, 1986; Harris \& Raviv, 1991; Kostyuk, 2011; Sinha, 2011). Few of these studies, however, have also examined international comparison of capital structure determinants (Wald, 1999; Rajan \&

\footnotetext{
* Corresponding author: jmsdoku@yahoo.com
}

DOI: $10.5937 /$ sjm 1102155D 
Zingales, 1995) as well as those in the context of developing countries (DemirgucKunt, 1992; Singh \& Hamid, 1992; Booth et al., 2001). Empirical works have identified firm characteristics, macroeconomic variables and country institutional factors as determinants of capital structure of firms (Booth et al., 2001).

Though capital structure literature is replete with studies in the developed and selected developing countries, there is a dearth of similar studies on how the development in the financial environment of a firm affects financing decisions of listed firms. Few studies that sought to explore this issue in selected developed and developing countries show inconclusive results (Demirguc-Kunt \& Maksimovic, 1996; Agarwal \& Mohtadi, 2004; Abor \& Biekpe, 2006). This provides scope for further empirical testing. Firms in developing countries especially in Africa are limited with regards to available financing which is mainly from the commercial banks. Financial sector reforms were considered as a better means of mobilising funding for investment and economic growth and exposing firms to variety of funding available. Ghana is one of the African countries that embarked on extensive financial reforms led by policies from the World Bank and IMF. The results of the reform have been touted to have been very successful and would have exposed local firms to financing options in both the banking sector and stock market. This paper therefore seeks to explore the impact of financial market development on the financing choices of listed firms in Ghana.

The paper contributes to the existing literature in a number of ways: first, it extends the existing empirical literature by examining whether banking sector and stock market act as complements or substitutes in financing decisions of listed firms in a developing country like Ghana. Finally, to the best of the author's knowledge, no formal empirical test has been conducted in Ghana concerning the impact of financial market development on financing decisions of listed firms.

The rest of the paper is organised as follows: the next section provides an overview of Ghanaian financial market development during the post independence era; relevant literature review is examined in section three; section four provides a discussion of empirical model and results and section five discusses conclusions .

\section{AN OVERVIEW OF GHANA'S FINANCIAL DEVELOPMENT MARKET}

After independence in 1957, Ghana became one of the countries in the West African sub-region with positive signals of growth prospects. The adoption of controlled credit allocations based on a centralist economic planning system however, began to have adverse effects on the financial sector and the general economy. By the late 1960 s to early 1970 s, there was little incentive for bank lending due to controlled interest rate regime. This resulted in severe credit shortage to private sector with credit directed mainly to government priority sectors such as agriculture and manufacturing. Between the 1970s and 1980s, government intervention in the financial system eroded the public confidence in the banking system. For instance, a currency conversion policy implemented in 1979 followed by a demonetisation of the 50 Cedi note in 1982, 


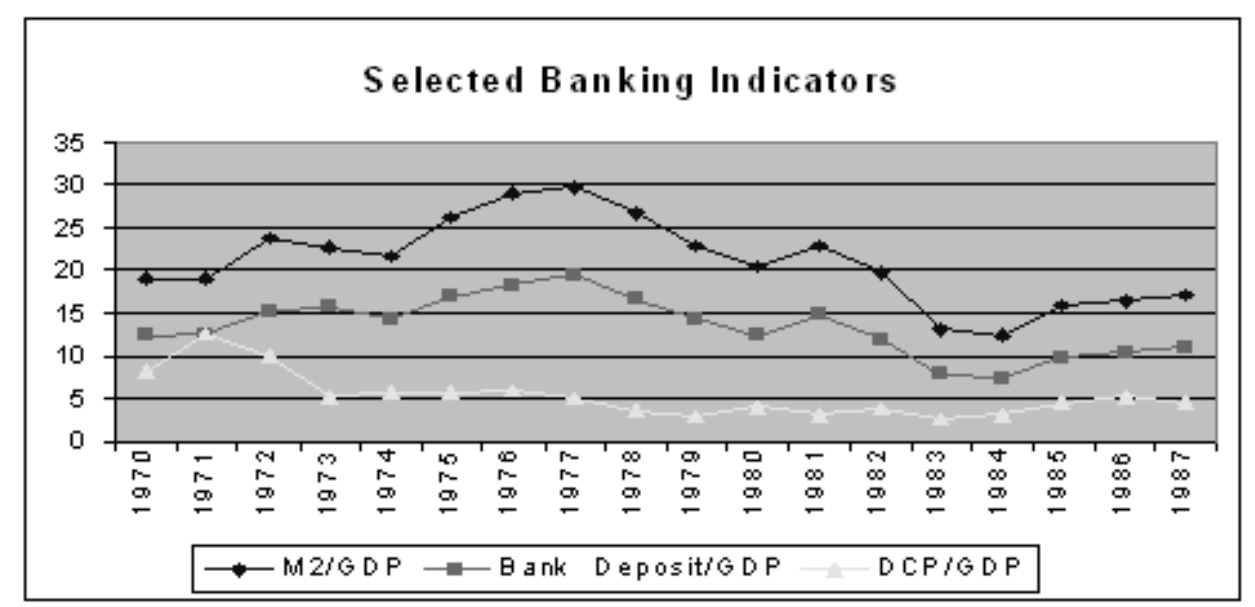

Figure 1. Selected Banking Indicators in Ghana (Source: Bank of Ghana Annual Reports (various issues) and Quarterly Digest of Statistics (various issues))

the restriction on modes of financial transactions for trade financing and the freezing of bank deposits in excess of 50,000 cedis $^{1}$ resulted in a severely repressed system, negative real interest rates, high inflation $(123 \%$ by 1983$)$ and led to erosion of confidence in the financial sector.

Financial debt as measured by M2/GDP declined from $20.4 \%$ of GDP in 1980, to $12.5 \%$ in 1984 . The general public lost confidence in the financial system leading to more currency outside the banking system. Ghanaians preferred keeping their money in physical assets and in the informal financial system (Aryeetey and Gockel, 1990). This had limited the ability of the banks to effectively perform their intermediation role and supply credit to the priority sectors of the economy as well. The banks' total deposits as a percentage of GDP amounted to $7.4 \%$ in 1984, having declined from $12.4 \%$ in 1970 .

The figure 1 throws more light on the money supply, bank deposits and credit to the private sector as a percentage of GDP.

By 1980, the Ghanaian financial system was in severe financial repression with the public banks being financially distressed. Thus, it was comprehensible that the 1 - The Ghanaian local currency economy needed to be reformed. The financial sector reforms started under the broad framework of Economic Recovery Programme (ERP) in the 1980s with the aim of removing the sectorial credit ceiling, liberalising the interest rates and restructuring the distressed banks. Laeven (2003) indicates that financial liberalization in developing countries minimises financing constraints of firms, particularly smaller ones. Love (2003), studied a sample of 36 countries and indicated that financial development affects firms' investment by increasing the availability of external finance. By 1986, there was a consistent attempt at steady increases in the interest rate, coupled with the gradual removal of credit ceilings, retirement of government debts to banks and restructuring of the banking system. There was also the introduction of auction bills and bonds to absorb excess liquidity; the establishment of a stock exchange by 1991, and the further development of the non-bank financial sector.

The economy responded appreciably to the widespread economic reforms. Real GDP increased steadily upward. Inflation declined 


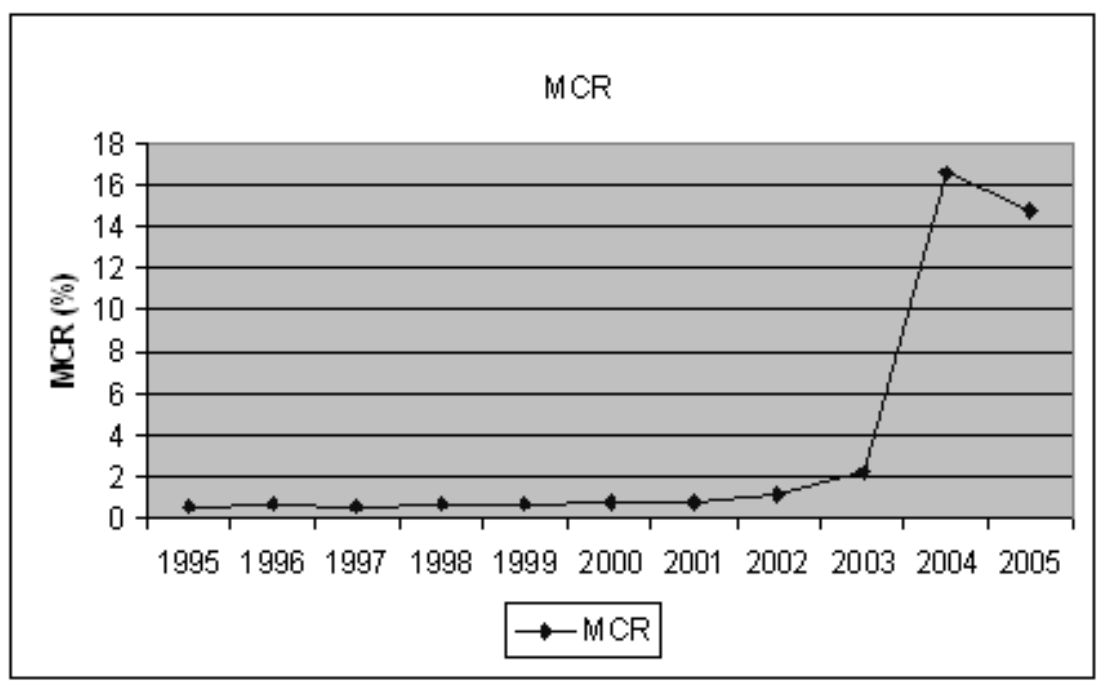

Figure 2. Ghana Stock Exchange Market Capitalisation Ratio (Source: Ghana Stock Exchange Statistics and author's own calculation)

from $123 \%$ in the late 1970 s and by 1993 , it was less than $20 \%$. The banking sector developed rapidly leading to a proliferation of banks and a diversification in banking activities. The trends in M2/GDP rose, indicative of some financial deepening after the reforms. Domestic credit also gained an upward trend. Credit to the private sector also increased substantially after the reforms. In addition, the introduction of an hitherto non-existent capital market in the financial structure of Ghana in the early 1990 s, also further enriched the financial landscape, opening up options for firms in terms of their financing decisions.

On the capital market scene, The Ghana Stock Exchange (GSE) which began trading in 1991, has been instrumental in raising equity capital for firms in Ghana and though a very small and largely illiquid market, the GSE has made some mark on the financial landscape of Ghana.

Table 2 shows the trend in market capitalization to GDP of the Ghana Stock Exchange and gives evidence of resource mobilisation and the size of the Ghana Stock
Exchange. The market capitalization ratio maintained a steady rise from the inception of the GSE until 2004 when it had a sharp rise to $17 \%$. This trend shows the growing importance of the GSE on the financial landscape of Ghana. It also shows that firms are increasingly being exposed to options other than bank debt to raise capital. With these trends and developments, it would be interesting to find out in further details on factors that influence financing decisions of firms in Ghana, and to also find out if the growth of the stock market is substituting bank finance or complementing it.

\section{OVERVIEW OF RELEVANT LITERATURE}

The on-going debate about the determinants of a firm's financing decision otherwise referred to as capital structure in finance literature started with the celebrated work of MM (1958). The MM (1958), argued that financial leverage is unrelated to a firm's value. This has invited several 
criticisms and provided scope for further examination of the factors affecting firms' financing decisions in realistic world that cannot be described as perfect. Thus, we have the trade-off theory and pecking order theory all attemting to provide an explanation to the issue.

Accordng to the trade-off hypothesis, financial managers consider a firm's optimum debt-equity decision as a trade-off between the benefits of using more debt and the costs of debt. The optimum capital structure involves a trade-off among the effects of corporate and personal taxes, bankruptcy costs and agency costs. This theory predicts that firms with safe, tangible assets and earning enough taxable income are expected to have high levels of debt ratio since debt servicing would not seem to be in difficulty.

Unlike the trade-off theory, the Pecking Order Theory (POT) holds that there is no such theoretical, well-defined target of debtequity mix, and that due to information asymmetry between insiders and outsiders of firms, managers prefer internal financing to external financing. The main assumption, according to this theory is that managers act in the interest of existing shareholders in maximising the value of existing shares. This theory explains that profitable firms are expected to have low debt ratios because they are expected to borrow less whereas less profitable firms are expected to have high debt ratio because they do not have sufficient internal funds for their investment projects. Shyam-Sunders \& Myers (1999) found support for this theory in a panel of 157 firms. However, Brennan and Kraus (1987); Noe (1988); Constantinides \& Grundy (1989) hold a different opinion. They show that firms do not necessarily prefer issuing debt to equity if a richer set of financing options are available. It appears that none of the above theories could conclusively and exhaustively explain what the determinants of capital structure of firms are.

\subsection{Financial Market Development and Firm Financing Decision}

Financial markets (including banking sector and stock market) provide an avenue for firms to raise either debt or equity capital or both. Well developed stock markets provide liquidity, diversification, and information acquisition, resource mobilisation for corporate finance, investment and growth. An active and liquid stock market makes it easy and relatively cheaper for firms to finance their operations through equity capital. Firms may therefore substitute long-term debt with equity and this would certainly affect their capital structure. On the other hand, an active stock market reveals information about listed firms to the market. Grossman (1976) and Grossman \& Stiglitz (1980), point out that the stock market provides essential information about listed firms and helps creditors make lending to listed firms less risky. Monitoring costs by both financial intermediaries and potential investors equally reduce. In this regard, the issue of information asymmetry and moral hazard are thus minimised. Demirguc-Kunt \& Maksimovic (1996), add that the stock market provides incentives for investors' acquisition of information. As the market for publicly traded stocks grows in size, it becomes more lucrative for analysts and investors to invest in acquiring information especially for more liquid stocks. According to Demirguc-Kunt \& Maksimovic (1999), this facilitates external monitoring of firms.

Asymmetric information has long been identified as a pervasive problem in financial 
markets. Most theoretical and empirical analyses in the banking literature indicate that banks simply help minimise problems arising from information asymmetries between firms and debtholders through monitoring. Diamond (1984), observed that banks act as delegated monitors of borrowers on behalf of depositors. Empirical evidence indicates that bank-firm relationship is crucial in financing decision of firms. Petersen \& Rajan (1994), find that small firms that have long-term relationship with banks (controlling for firm age), have greater access to credit when they rely on a single bank rather than multiple banks. Berger \& Udell (1995), find that a longer bankcustomer relationship (again controlling for firm age) reduces interest rates and collateral requirements on loan commitments. Hoshi et al. (1990, 1991), find that Japanese firms that have long-term relationships with banks (members of a keiretsu), face lower costs of financial distress as compared to nonmember firms. Slovin et al. (1993), distinguish the uniqueness of bank loans from securities, and found that bank borrowers incurred negative abnormal returns during bank's impending failure. This is indicative of the specialty of bank loan. Gilson et al. (1990), observed that when firms are in financial distress and bankruptcy, they are likely to renegotiate for their debt restructuring. Such debt restructuring directly depends on the extent of the firm's reliance on bank borrowing. Of course, it is easier to renegotiate with a single bank or small number of banks than scattered number of equity holders, in which case a free rider problem arises. Empirical evidence indicates that banks provide certain essential services that cannot be replicated in the capital market. The above scenarios may suggest that it is conceivable that activities of financial intermediaries in the financial market could be described as complementary to the capital market development in the financing of firms.

Empirical evidence on financial markets and capital structure of firms are not very extensive in emerging markets context. Antoniou et al. (2002), find that the capital structure choice of a firm is affected by the existence of a stock market as well as the size of banking sector. Abor \& Biekpe (2005), have also added to the general evidence that firm characteristics affect capital structure of firms in Ghana. Abor et al. (2005), examined how firms determine their capital structure in a dynamic setting in Ghana. Macroeconomic, stock market and banking indicators were used to determine the financing decision of listed firms in Ghana. They find that the Ghana stock market is an important source of long-term financing for listed firms. Yartey (2002), finds that "compared with corporations in advanced countries, the average quoted Ghanaian firm finances a large proportion of its growth of total assets from external sources and therefore relies to a much smaller extent on internal finance".

\section{DATA AND ECONOMETRIC METHOD}

\subsection{Data}

The study used annual data computed from the Factbook of Ghana Stock Exchange over eleven years. Data used include stock market capitalisation ratio which measures the size of the stock market and its ability to mobilise funds, volume of shares traded ratio (a measure of liquidity of traded equity of firms), turnover ratio (a measure of liquidity 
and transaction cost), domestic banks assets ratio (a measure of financial intermediation by domestic banks), banks' liquid liability to GDP ratio and selected firm level characteristics. The study used panel data which involves pooling of twenty-one listed firms on the Ghana Stock Exchange (GSE) over the period 1995-2005.

\subsection{Model Specification}

This study adopts the model used by Demirguc-Kunt \&Maksimovic (1999) and subsequently adopted by Agarwal \& Mohtadi (2004) and Abor * Biekpe (2006). This model assumes that a firm's debt-equity ratio, $\mathrm{DE}$, is a function of a vector, $\mathrm{X}$, of independent variables. These variables include the stock market indicators, banking indicators and firm-specific variables. The model is generally specified as in the following form:

$$
\mathrm{DE}_{\mathrm{it}}=\beta \mathrm{X}_{\mathrm{it}}+\delta_{\mathrm{i}}+\mathrm{y}_{\mathrm{t}}+\varepsilon_{\mathrm{it}}
$$

where

DEit $=$ Debt-equity ratios: short-term and long-term debt ratios for firm $i$ in time $t$.

$\mathrm{X}=$ Vector of explanatory variables: stock market indicators, banking indicators and firm level characteristics.

$\beta=$ Vector of coefficient of explanatory variables

$\delta \mathbf{i}=$ Firm specific effects

$\mathrm{yt}=$ Time specific effects

$\varepsilon i t=$ Error term

This model is used to determine the effect of financial market development indicators on financing decision of firms. A negative coefficient of the stock market indicators would mean leverage falls as the stock market develops and vice versa. This implies that a firm employs more equity as against debt with a marginal development of the stock market.

Following Demirguc-Kunt \& Maksimovic (1999), and Abor \& Biekpe (2006), this study also examined whether listed firms in Ghana maintain set target debt-equity ratio or pattern. Thus, we introduce into the model, lagged dependent variable. This is stated below:

$$
\mathrm{DE}_{\mathrm{it}}=\beta \mathrm{X}_{\mathrm{it}}+\alpha \mathrm{DE}_{\mathrm{it}-1}+\delta_{\mathrm{i}}+\mathrm{y}_{\mathrm{t}}+\varepsilon_{\mathrm{it}}
$$

When the coefficient of the lagged variable is below unity, it indicates that firms maintain specific debt-equity level which does not change with time and when it is greater than unity, it denotes firms vary their debt-equity level as the economy/financial market develops.

\subsection{Discussion of Empirical Results}

Summary descriptive statistics (table 1) shows that short-term debt constitutes a large percentage (with a mean of 94\%) of financing when compared to long-term debt with a mean of a little over $39 \%$. This indicates the more reliance of firms on shortterm financing option in the Ghanaian financial market. In the case of value traded and turnover ratios, a mean of $3.5 \%$ and $1.956 \%$ are indicative of low liquidity of the market.

\subsection{Regression Results}

The study estimated static and dynamic panel regressions. In all cases, the Hausman test (see table 2) results does not accept the fixed effects results. Hence, we report the random effects results. 
Table 1. Descriptive Summary Statistics

\begin{tabular}{|l|c|c|c|c|c|c|}
\hline Variable & Obs & Mean & Median & Std. Dev & Min & Max \\
\hline Size & 11 & 7531625 & 458340 & 6168020 & 21212195 & $2.04 \mathrm{E}+08$ \\
\hline Growth & 11 & 0.39005 & 0.31379 & 73.6877 & 0.01358 & 0.84930 \\
\hline ROA & 11 & 0.03573 & 0.02900 & 0.11175 & -0.26000 & 0.18800 \\
\hline Div/ta & 11 & 0.02426 & 0.01688 & 0.03349 & 0.00297 & 0.124151 \\
\hline Std/eq & 11 & 0.94144 & 0.87351 & 0.29970 & 0.55096 & 1.549096 \\
\hline Ltd/eq & 11 & 0.39625 & 0.28601 & 0.35807 & 0.06644 & 1.184312 \\
\hline Tangibility & 11 & 0.47198 & 0.47645 & 0.11978 & 0.30392 & 0.74254 \\
\hline Capitalisation ratio & 11 & 3.59442 & 0.73736 & 6.00873 & 0.58668 & 16.56004 \\
\hline Value traded ratio & 11 & 0.03452 & 0.01795 & 0.03473 & 0.00670 & 0.111271 \\
\hline Turnover ratio & 11 & 0.01956 & 0.01446 & 0.01228 & 0.00505 & 0.041289 \\
\hline Liquid liability ratio & 11 & 0.26109 & 0.26700 & 0.05829 & 0.18140 & 0.33900 \\
\hline Domestic banks asset ratio & 11 & 0.03211 & 0.02925 & 0.01500 & 0.01536 & 0.06034 \\
\hline
\end{tabular}

\subsubsection{Stock Market Variables}

The stock market capitalisation ratio shows a statistically positive and significant relationship to leverage. From table 2, a one percent increase in the market capitalisation ratio results in $5.18 \%$ and $0.87 \%$ increases in short term and long term debt ratios respectively. This actually indicates that the capital market development enhances the ability and opportunity of listed firms to increase and diversify their holdings of and access to long-term and short-term debt from the financial market. Developments in the capital market convey vital information to investing public. This result may suggest the critical importance investors attached to the development on the stock market and financing decisions of listed firms. On the one hand, it implies that as the stocks of the listed firms grow in size, they become more attractive to the investing public and thus, enabling the listed firms to increase their holdings. On the other hand, monitoring cost by financial intermediaries reduces with positive developments on the capital market. Hence, more willingness to lend to the listed firms.

Thus, this finding underpins the positive role played by the stock market in conveying information about prospects of listed firms to financial market participants (Grossman, 1976; Grossman and Stiglitz, 1980). Similar studies confirm this outcome (DemirgucKunt and Maksimovic, 1996; Agarwal and Mohtadi, 2004 and Abor, 2006). Similarly, the turnover ratio which measures transaction cost as well as the liquidity of firms' trading on the market, produces a positive relationship with regards to both long-term and short-term debt ratios. Implication wise, an improvement in the turn over ratio would not only enhance firms' attractiveness to investors on the market (more access to equity financing), but also provides an indication of good prospects to financial intermediaries. Hence, more access to both short and long term debt financing to listed firms.

However, the results of value of shares traded to GDP produces a statistically significant and negative coefficients relating to both the short-term and long-term debt ratios. The value of shares traded over the GDP ratio measures size as well as liquidity on the market. This may be interpreted to mean that the more liquid a firm's securities being traded on the exchange are, the more 
Table 2. The Random-effects Regression Result (Static)

\begin{tabular}{|c|c|c|c|c|c|c|}
\hline & \multicolumn{3}{|c|}{ Short-term Debt } & \multicolumn{3}{|c|}{ Long-term Debt } \\
\hline Variable & $\mathbf{B}$ & z-value & $\begin{array}{c}\text { p- } \\
\text { value }\end{array}$ & B & z-value & $\begin{array}{c}\text { p- } \\
\text { value }\end{array}$ \\
\hline Constant & -1.409 & -1.62 & 0.105 & -8.81 & -1.64 & 1.102 \\
\hline $\log ($ Size $)$ & -0.257 & $-4.78 * * *$ & 0.000 & 0.695 & 0.40 & 0.687 \\
\hline Growth & -0.001 & -0.33 & 0.741 & 0.005 & $7.58^{* * *}$ & 0.000 \\
\hline ROA & 7.483 & $4.90^{* * *}$ & 0.000 & 6.31 & $3.33^{* * *}$ & 0.000 \\
\hline Div/ta & $\begin{array}{l}-1.12 \mathrm{e}- \\
07\end{array}$ & -0.17 & 0.868 & 0.509 & $3.00^{* * *}$ & 0.000 \\
\hline Tangibility & 0.004 & $3.58^{* * *}$ & 0.000 & -0.024 & -0.46 & 0.646 \\
\hline $\begin{array}{ll}\text { Capitalisation } & \text { ratio } \\
\text { (MCR) } & \end{array}$ & 5.184 & $5.71^{* * *}$ & 0.000 & 0.874 & $2.40 * *$ & 0.016 \\
\hline $\begin{array}{l}\text { Value traded ratio } \\
\text { (TVT/GDP) }\end{array}$ & -3.659 & $-13.38 * * *$ & 0.000 & -0.338 & $-13.95 * * *$ & 0.000 \\
\hline Turnover ratio (TOR) & 2.799 & $28.88 * * *$ & 0.000 & 0.168 & $5.92 * * *$ & 0.000 \\
\hline Liquid liability ratio $M 2+G D P$ & 0.001 & 0.18 & 0.860 & 1.041 & $13.53 * * *$ & 0.000 \\
\hline Domestic banks asset ratio & 3.120 & 0.94 & 0.347 & -0.535 & $-6.35 * * *$ & 0.000 \\
\hline Wald chi2(10) & \multicolumn{3}{|c|}{89} & \multicolumn{2}{|c|}{ Wald chi2(10) } & 213 \\
\hline Prob $>$ chi2 & 0.000 & & & \multicolumn{2}{|c|}{ Prob $>$ chi2 } & 0.000 \\
\hline Hausman test $\chi^{2}(7)$ & 10.01 & & & \multicolumn{2}{|c|}{$\begin{array}{l}\text { Hausman test } \chi^{2} \\
\text { (7) }\end{array}$} & 11.00 \\
\hline \multirow[t]{2}{*}{ p-value } & 0.1882 & $\begin{array}{l}\text { No. of } \\
\text { Obs }\end{array}$ & 201 & \multicolumn{2}{|c|}{ p-value } & 0.1384 \\
\hline & & R-sq: & $48.19 \%$ & \multicolumn{2}{|c|}{ R-Sq: } & $73.25 \%$ \\
\hline
\end{tabular}

Notes: $* *$ and $* * *$ indicate statistical significance at level $5 \%$ and $1 \%$ respectively. . Log (Size) is log of total assets, Growth is change in sales, ROA is earning after interest and tax divided by total assest, Div/ta is dividend divided by total assets, Tangibility is fixed assets divided by total assets, MCR is stock market capitalisation divided by GDP, TVT is Valume of shares traded divided by GDP, TOR, turnover ratio (MCR/TVT), Banks asset over GDP is Domestic banks assets ratio, and M2+/GDP is banks'liquid liability to GDP ratio

access to equity financing. This may be related to long-term debt, but negatively possible when transaction cost involved in related to short-term debt even though this is equity financing becomes less with the not statistically significant. The positive development in the stock market, compared relationship with regards to long-term debt to the usual cumbersome procedures and requirements demanded by financial intermediaries, especially in developing countries where banking sector cannot be described as competitive. Thus, in the context of a developing economy like Ghana, further development of the financial landscape will see debt and equity financing at a point being discriminated upon by firms.

\subsubsection{Banking Indicators}

From table 2 the coefficient of M2+/GDP ratio is statistically significant and positively shows that as the banking sector develops, firms gain increased access to debt, underscoring the importance of debt financing. More importantly, the positive relationship between banking sector development indicators and long-term debt as well as stock market development and long-term debt, confirms complementarity between banks and stock markets in financing firm growth.

\subsubsection{Firm Level Variables}

The existant literature identifies firms 
characteristics as determinants of firms financing decision. The log of the total assets which proxy for the size of the firm shows mixed outcomes. From table 2, the coefficient of the size of a firm is statistically significant and negatively related to shortterm debt ratio. By implication, large firms would access less of short-term debt. Another view is that large firms may be likely to face agency problem and therefore use less debt. This sharply falls in line with the finding of Ozkan (2001), who found size to be negatively related to leverage but insignificant. On the other hand, the size of the firm is positively related to the long-term debt ratio though statistically insignificant. This positive relationship is consistent with theory and empirical evidence (Rajan \& Zingales, 1995; Booth et al., 2001; Wald, 1999).

The profitability measure (ROA) point to one direction. From table 2, returns on assets is statistically significant and positively related to both short-term debt and long-term debt ratios. This finding contradicts the POT, Friend \& Lang (1988), Kester (1986), Titman \& Wessels (1988), and Bevan \& Danbolt (2002), which posits that profitable firms should use less debt. On the other hand, this result confirms the work of Um (2001) and Jensen (1986), and may mean that profitable firms listed on the exchange prefer more use of debt which servicing might not be of trouble to them. Growth opportunities variable produces mixed results. It produces negative and statistically insignificant coefficient with regards to short-term debt, but positive and significant relationship with long-term debt ratio. The positive relationship confirms findings of Toy et al. (1974), and Baskin (1989). The positive relationship may indicate that firms with growth opportunities have more access to both debt and equity financing. Also, debt and equity financing may appear as complements to long-term financing needs of listed firms with growth opportunities.

Another firm level variable which produces mixed results is tangibility. The result shows tangibility is statistically significant and positively related to shortterm debt ratio. By implication, firms with more tangible assets would be able to access more debt. In this study, more of short-term debt would be accessed by tangible firms listed on the GSE. This finding is similar to that of other empirical findings (Williamson, 1988; Harris \& Raviv, 1990). Differing views have been put forth concerning dividend policy in finance. A firm that pays dividend is viewed as sending positive signals to market participants and its stakeholders about its prospects. This firm can access more debt. On the other hand, inability to pay dividends could potentially constrain shareholders liquidity position thereby, sending bad signals to them. Fama \& Jensen (1983), contend that large dividend payment reduces conflict of interest among stakeholders of a firm. Thus, one would expect a positive association between leverage and dividend pay. The result from this work shows there is a positive and statistically significant relationship between dividend pay and long-term debt. By implication, listed firms in Ghana can attract more long-term debt through appropriate positive signals when more dividends are paid to shareholders.

From table 3, we present the dynamic estimation result where we lagged and included in the right-hand side of the equation, lagged dependent variable. The lagged short-term and long-term debt-equity ratios show statistically significant and inverse relationship concerning short term 
Table 3. Dynamic Model Result

\begin{tabular}{|c|c|c|c|c|c|c|}
\hline & \multicolumn{3}{|c|}{ Short-term Debt } & \multicolumn{3}{|c|}{ Long-term Debt } \\
\hline Variable & $\beta$ & t-value & p-value & $\beta$ & t-value & p-value \\
\hline Constant & -0.731 & -0.15 & 0.884 & 0.481 & 9.14 & 0.000 \\
\hline Debt-Equity ratio $_{t-1}$ & -0.000 & $-10.24 * * *$ & 0.000 & -0.000 & $-2.89 * * *$ & 0.004 \\
\hline $\log ($ Size) & -0.208 & $-5.84 * * *$ & 0.000 & 0.011 & $3.77 * * *$ & 0.000 \\
\hline Growth in Sales & 0.002 & 1.13 & 0.258 & 0.000 & 0.97 & 0.332 \\
\hline Return on Asset & 3.406 & $3.92^{* * *}$ & 0.000 & -1.555 & $-21.74 * * *$ & 0.000 \\
\hline Dividend/total asset & -0.660 & -0.53 & 0.597 & -0.085 & -0.81 & 0.415 \\
\hline Tangibility & -6.976 & $-21.08 * * *$ & 0.000 & -0.440 & $-16.26 * * *$ & 0.000 \\
\hline Capitalisation/gdp $\mathrm{MCR}$ & 2.479 & 4.89 & 0.000 & 0.401 & $9.56^{* * *}$ & 0.000 \\
\hline Value traded ratio (TVT) & -3.101 & $-17.58^{\star \star \star}$ & 0.000 & -0.398 & $-26.97^{\star \star \star}$ & 0.000 \\
\hline $\begin{array}{ll}\text { Turnover ratio } & \mathrm{MCR} / \mathrm{TVT} \\
\end{array}$ & 1.275 & $12.71 * * *$ & 0.000 & 0.218 & $26.85^{* * *}$ & 0.000 \\
\hline M2/gdp & 0.004 & 1.05 & 0.292 & -0.001 & $-3.15^{* * *}$ & 0.002 \\
\hline Domestic banks' asset/gdp & 25.912 & $11.34 * * *$ & 0.000 & 2.108 & $11.04 * * *$ & 0.000 \\
\hline Wald chi2(11) & \multicolumn{3}{|c|}{9.76} & \multicolumn{2}{|c|}{ Wald chi2(11) } & 7.61 \\
\hline Prob>chi2 & 0.000 & & & \multicolumn{2}{|c|}{ Prob $>$ chi2 } & 0.000 \\
\hline Hausman test $\chi^{2}(9)$ & 2.49 & & & \multicolumn{2}{|c|}{ Hausman test $\chi^{2}(9)$} & 1.37 \\
\hline p-value & 0.2264 & & & \multicolumn{2}{|c|}{ p-value } & 0.1619 \\
\hline & & R-sq: $51.94 \%$ & & \multicolumn{2}{|c|}{ R-sq: } & $64.4 \%$ \\
\hline
\end{tabular}

Notes: $* *$ and $* * *$ indicate statistical significance at level $5 \%$ and $1 \%$ respectively

and long-term debt-equity ratios. The most important result here is that the coefficients of these lagged variables are less than unity indicating that debt-equity ratios remain stable over time. Listed firms in Ghana do not change their debt-equity mix substantially over time.

\section{CONCLUSION}

This study explored the relationship between financial market development and choice of finance (debt-equity) of listed firms in Ghana. With the development of the financial market in a developing economy like Ghana, firms would be exposed to more financing options in attempt to minimise financing constraints, reliance on one source of finance and above all, minimise market inefficiencies that may give rise to suboptimal financial contracting. The core concern of this study is whether debt and equity finance are complements or substitutes. The study finds that aside firm specific factors recognized in extant literature as responsible in explaining financing choices of firms, financial market development also accounts for financing decisions of listed firms. Generally, the study finds that debt and equity financing are important complements that increase firms' access to finance and hence, debt-equity ratio as the financial market develops. However, substitution effect sets in at a point in time between debt and equity mainly in favour of equity financing. Listed firms prefer entering long term equity financing contracts as the financial landscape develops further. This is laudable, in view of important roles equity markets in developing countries are supposed to play in economic development efforts.

The findings from this study have some 
implications for policy issues. This lies in the importance of long term finance from the capital market to complement bank-finance growth. Firms in developing nations have limited their funding option to mainly loans from commercial banks. Nonetheless, given the revelation of the importance of the capital market in Ghana, firms' reliance on bank debt may be minimised. Thus, regulatory policies that will safegaurd the capital market integrity and investor confidence should be pursued. Government and monetary authorities should therefore apply prudent macroeconomic stabilisation policies to accelerate the development of the financial market, promote actively other alternative sources of funding like the venture capital and microfinance. It would also be interesting for the banking sector which forms a major component of the financial system to develop innovative financial products for financing firms that are in need of funds. Future studies should investigate this phenomenon by incorporating corporate governance variables to see how financing decisions of listed firms would be altered.

\title{
РАЗВОЈ ФИНАНСИЈСКОГ ТРЖИШТА И СТРУКТУРА КАПИТАЛА РЕГИСТРОВАНИХ КОМПАНИЈА - ЕМПИРИЈСКА РАЗМАТРАњА СИТУАЦИЈЕ У ГАНИ
}

\author{
James N. Doku ${ }^{\text {* }}$, Charles Komla Delali Adjasib and \\ Emmanuel Sarpong-Kumankumac

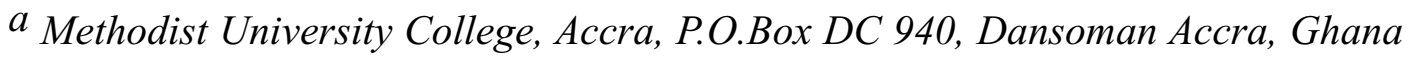 \\ ${ }^{b}$ University of Stellenbosch Business School, Cape Town, \\ P O Box 610, Bellville 7535, South Africa \\ ${ }^{c}$ University of Ghana Business School, Accra Ghana, P.O.Box LG 78 Legon, Ghana
}

\section{Извод}

Ова студија истражује зависност између развоја финансијског тржишта и избора начина финансирања (задуженост), регистрованих фирми у Гани, у виду оквирног панела. Суштински циљ студије је да тестира да ли су задуживање и финансирање преко акција комплементи или субститути. Студије користи панел податке који укључују анализу двадесте и једне регистроване фирме на берзи акција у Гани, током период 1995 - 2005. Студије проналази комплементарност између развоја банкарског и берзанског развоја и њиховог утицаја на одлучивање о финансирању компанија регистрованих у Гани. Развој тржишта акција има позитиван ефекат на одлуке о структури капитала ових фирми. Ипак, ефекат супституције између кредитног задуживања и пласирања акција, који више иде ка фаворизовању акција утиче на правац даљег развоја финансијског тржишта. Ови резултати истраживања указују на то колико значајну улогу има тржиште акција у земљама у развоју.

Кључне речи: Развој финансијског тржишта, Структура капитала, Комплементарност, Субститут, Гана 


\section{References}

Abor, J., Adjasi, C., \& Biekpe, N. (2005). Determinants of Financing Choices of Firms in a Dynamic Setting. Working Paper, University of Ghana Business School.

Abor, J., \& Biekpe, N. (2005) What Determines the capital structure of Ghanaian Firms. African Finance Journal, 7(1): 37-48.

Agarwal, S., \& Mohtadi, H. (2004) Financial Markets and the Financing Choice of Firms:Evidence from Developing Countries. Global Finance Journal, 15: 57-70.

Antoniou, A., Guney, Y., \& Paudyal, K. (2002). Determinants of Corporate Capital Structure: Evidence from European Countries. Working paper, University of Durham.

Aryeetey, \& Gockel, A.F (1990) Mobilising Domestic Resources for Capital Formation in Ghana. The Role of Informal Financial Markets, AERC Research Paper 3, Nairobi, Kenya.

Baskin, J.B. (1989) An Empirical Investigation of the Pecking Order Hypothesis. Financial Management, 18: 2635.

Berger, Allen, N., \& Gregory, F. U. (1995) Relationship Lending and Lines of Credit in Small Firm Finance. The Journal of Business, 68(3): 351-381.

Bevan, A., \& Danbolt, J. (2002) Capital structure and its determinants in the UK- a decompositional analysis. Applied Financial Economics, 12:159-170.

Booth, L., Aivazian, V., Demirguc-Kunt, A., \& Maksimovic, V. (2001) Capital Structures in Developing Countries. Journal of Finance, 56(1):87-130.

Brennan, M., \& Alan, K. (1987) Efficient financing under asymmetric information. Journal of Finance, 42: 1225-1243.

Constantinides, G.M., \& Bruce, D.G.
(1989)mOptimal investment with stock repurchase and financing as signals. The Review of Financial Studies, 2: 445-466.

Demirguc-Kunt, A. (1992) Developing Country Capital Structure and Emerging Stock Markets. World Bank Working Paper series.

Demirguc-Kunt, A., \& Maksimovic, V., (1996) Stock Market development and Firm Financing choices. World Bank Economic Review 10:341-369.

Demirguc-Kunt, A., \& Maksimovic, V. (1999) Institutions, financial markets, and firm debt maturity. Journal of Financial Economics, 54:295-336.

Diamond, D. (1984) Financial intermediation and delegated monitoring. Review of Economic Studies, 51: 393-414.

Fama, E.F, \& Jensen, M. (1983) Separation of Ownership and Control. Journal of law and Economics, 26:301-325.

Friend, I., \& Lang, L. (1988) An Empirical test of the impact of managerial self-interest on capital structure. Journal of Finance, 43: 271-281.

Gilson, S., John, K., \& Lang, L. (1990) Troubled Debt Restructuring: An Empirical Study of Private Reorganizations of Firms in Default. Journal of Financial Economics, 27:315-353.

Grossman, S.J. (1976) On the efficiency of Competitive stock markets where traders have diverse information. Journal of Finance, 31:573-585.

Grossman, S., \& Stiglitz J. (1980) On the Impossibility of Informationally Efficient Markets. American Economic Review, 61:393-408.

Harris, M., \& Raviv, A. (1990) Capital structure and the informational role of debt. Journal of Finance, 45 (2):321-349.

Hoshi, T., Anil, K., \& David, S. (1990b) The Role of Banks in Reducing the Costs of 
Financial Distress in Japan. Journal of 49 (1):3-37.

Financial Economics, 27: 67-88.

Hoshi, T., Anil, K., \& David, S. (1991) Corporate Structure, Liquidity and Investment: Evidence from Japanese Industrial Groups. Quarterly Journal of Economics, 106: 33-60.

Jensen, Michael C. (1986)Agency costs of free cash flow, corporate finance and takeovers. American Economic Review, 76:323-339.

Kester, V. (1986) Capital Structure Ownership Structure: A comparison of United States and Japanese Manufacturing Corporations. Financial Management:5-16.

Kostyuk, A. (2011) Corporate governance in banking sector in transition economy: the role of ownership structures. Serbian Journal of Management, 6(1): 43-54.

Laeven, L. (2003) Does financial liberation reduce financing constraints? Financial Management, 32(1):5-34.

Love, I. (2003) Financial development and financing constraints: International evidence from the structural investment model. Review of Financial Studies, 16(3): 765-791.

Modigliani, F., \& Miller, M., (1958) The Costs of capital, Corporate Finance and Theory of Investment. American Economic Review, 48:261-297

Modigliani, F., \& Miller, M. (1963) Corporate Income taxes and the Cost of capital: A Correction. American Economic Review, 53, June: 443-453.

Noe, T. (1988) Capital structure and signalling game equilibria. Review of Financial Studies, 1:331-356.

Ozkan, A. (2001) Determinants of Capital Structure and Adjustment to long-Run Target: Evidence from UK Company Panel Data. Journal of Business Finance and Accounting, 28: 175-198.

Petersen, M.A, \& Rajan, R.G. (1994) The benefit of lending relationships: Evidence from small business data. Journal of Finance,
Rajan, R., \& Zingales, L. (1995) What Do We Know about Capital Structure? Some Evidence from International Data. Journal of Finance, 50: 1421-1460.

Shyam-Sunder, L., \& Myers, S.C., (1999) Testing static trade-off against pecking order models of capital structure. Journal of Financial Economics, 51: 219-244.

Singh, A., \& Hamid, J. (1992) Corporate Financial Structures in Developing Countries. IFC Technical Paper No.1, Washington D.C., IFC.

Sinha, P. (2011) Short-term selling of a stock: a model. Serbian Journal of Management, 6(1): 2011.

Slovin, M., Marie S., \& John, P. (1993) The Value of Bank Durability: Borrowers as Bank Stakeholders. Journal of Finance, 48 (1): 247266.

Titman, S., \& Wessels, R. (1988) The determinants of Capital structure choice. Journal of Finance, 43:1-19.

Toy, N., Stonehill, A. Remmers, L. Wright, R., \& Beekhusen, T. (1974) A Comparative International Study of Growth, Profitability and Risk as Determinants of Corporate Debt Ratios in the Manufacturing Sector. Journal of Financial and Quantitative Analysis: 875-886.

Um, T. (2001). Determination of Capital Structure and Prediction of Bankruptcy in Korea, unpublished $\mathrm{PhD}$ thesis. Cornell University.

Wald, J.K. (1999) How Firm Characteristics Affect Capital Structure: An International Comparison. Journal of Financial Research, 22:161-187.

Williamson, O. (1988) Corporate finance and Corporate governance. Journal of Finance, 43:567-591.

Yartey, C.A (2002) The Stock Market and the Financing of Corporate Growth in Africa: The case of Ghana. IMF Working Paper, WP/06/201 IMF. 